\title{
Dokument
}

\section{Vladimir Putin i München}

Mange tak, ærede fru forbundskansler, hr. Teltschik (siden 1999 leder af sikkerhedskonferencen i München. I sin tid en af kansler Helmut Kohls nærmeste medarbejdere), mine damer og herrer!

Jeg er meget taknemlig over at være indbudt til en så repræsentativ konference, der samler politikere, officerer, forretningsfolk og eksperter fra mere end 40 lande i verden.

Konferencens format giver mig mulighed for at undgå 'overdreven høflighed' og nødvendigheden af at tale i runde og behagelige, men tomme diplomatiske klicheer. Konferencens format gør det muligt at sige, hvad jeg virkelig tænker om internationale sikkerhedsproblemer. Og hvis mine overvejelser forekommer vore kolleger for polemisk tilspidsede eller upræcise, beder jeg Dem om ikke at blive vred på mig det er jo kun en konference. Og jeg håber, at hr. Teltschik ikke tænder for 'det røde lys' en to-tre minutter inde i mit indlæg.

Det er en kendt sag, at problematikken vedrørende den internationale sikkerhed omfatter meget mere

$$
\begin{aligned}
& \text { Under den årlige Wehrkunde-konference i München holdt Ruslands } \\
& \text { præsident Vladimir Putin den 10. februar en tale, der fik Vesten til at tale } \\
& \text { om en ny kold krig. Og selv om Ruslands faste repræsentant ved EU Ser- } \\
& \text { gej Jastrzjembskij foretrak at tale om et koldt styrtebad, så ligger det fast, } \\
& \text { at talen var usædvanlig ligefrem og kritisk. Putins vrede var ikke mindst } \\
& \text { fremkaldt af den amerikanske beslutning om at indlede forhandlinger } \\
& \text { med Polen og Tjekkiet om etablering af missilforsvarsinstallationer. Ame- } \\
& \text { rikanernes officielle begrundelse er ønsket om at kunne forsvare sig mod } \\
& \text { enkeltstående missilangreb fra banditstater, men den nye amerikanske } \\
& \text { forsvarsminister Robert Gates havde kort forinden anmodet kongressen } \\
& \text { om større bevillinger til det amerikanske militær med henvisning til det } \\
& \text { stigende trusselsniveau i verden, herunder fra Rusland og Kina. På den } \\
& \text { baggrund benyttede Putin lejligheden til endnu en gang at slå fast, at en } \\
& \text { unipolær verdensorden er både uønsket og urealistisk. Vi bringer her ta- } \\
& \text { len i dens fulde ordlyd. }
\end{aligned}
$$


end spørgsmål vedrørende militærpolitisk stabilitet. Den omfatter stabilitet i verdensøkonomien, overvindelse af fattigdommen, økonomisk sikkerhed og udvikling af en dialog mellem civilisationerne.

Sikkerhedens altomfattende, udelelige karakter er også udtrykt i dens fundamentale princip: "Den enkeltes sikkerhed er alles sikkerhed." Som Franklin Roosevelt sagde allerede i de første dage efter Anden Verdenskrigs udbrud: "Hvor freden end brydes, er verden overalt i fare og truet." (I en radiotale til nationen den 3. september 1939 sagde Roosevelt: "When peace has been broken anywhere, the peace of all countries everywhere is in danger.")

Disse ord har ikke mistet deres aktualitet i dag. Det fremgår i øvrigt af emnet for vores konference, der er anført her: 'Globale kriser - globalt ansvar.'

For blot to årtier siden var verden ideologisk og økonomisk delt, og dens sikkerhed blev garanteret af de to supermagters enorme strategiske potentialer.

Den globale konfrontation skubbede yderst akutte $ø$ konomiske og sociale problemer ud i udkanten af de internationale relationer og dagsordenen. Som enhver anden krig efterlod 'den Kolde Krig' os 'ikke-eksploderede granater' - billedlig talt.

Jeg tænker på de ideologiske klicheer, dobbeltstandarderne og andre skabeloner fra bloktænkningen.

Den unipolære verden, der blev foreslået efter 'den Kolde Krig', er heller ikke blevet til noget.

Menneskehedens historie kender naturligvis også til perioder af unipolaritet og stræben mod verdensherredømmet. Hvad er der ikke sket i menneskehedens historie?

Men hvad er da den unipolære verden? Hvordan man end besmykker dette begreb, så betyder det $\mathrm{i}$ sidste ende kun én ting i praksis, nemlig ét ledelsescentrum, ét magtcentrum, ét center for beslutningstagning.

Det er én herres, én suveræns verden. Det er i sidste ende ødelæggende ikke blot for alle, som befinder sig inden for rammerne af dette system, men også for suverænen selv, fordi det ødelægger ham indefra.

Og det har selvfølgelig intet til fælles med demokrati. For demokrati - det er som bekendt flertalsmagt under hensyntagen til mindretallets interesser og meninger.

I øvrigt bliver Rusland - vi - bestandig belært om demokrati. Men de, der belærer os, har ikke selv megen lyst til at lære.

Jeg mener, at den unipolære model ikke er alene er uantagelig, men også umulig for verden i dag.

Og ikke kun, fordi der ved enkeltmandsledelse i verden i dag - netop i verden i dag - ikke ville være nok militær-politiske eller $\varnothing$ konomiske ressourcer. Men hvad der er endnu vigtigere: Selve modellen er ikke funktionsdygtig, fordi den i bund og grund ikke kan danne det moralsk- 
etiske grundlag for den moderne civilisation.

Samtidig er alt det, der sker i verden i dag - og vi er kun lige begyndt at diskutere det - det er en følge af, at man forsøger at indføre netop dette koncept i de internationale anliggender, den unipolære verdens koncept.

Hvad er resultatet?

Ensidige og ofte illegitime handlinger har ikke løst et eneste problem. Nej, de har forårsaget nye menneskelige tragedier og nye brændpunkter med spændte forhold. Døm selv: krige, lokale og regionale konflikter er der ikke blevet færre af. Hr. Teltschik mindede meget forsigtigt om det. Og der omkommer ikke færre mennesker i disse konflikter, men endog flere end før. Langt flere - langt flere.

I dag kan vi se en næsten uhæmmet, overdreven brug af magt $i$ internationale anliggender - af militær magt, en magt, der styrter verden ud i en malstrøm af konflikt på konflikt. Følgen er, at der ikke er kræfter til at løse en eneste af dem. Også en politisk løsning af dem bliver umulig.

Vi kan se en stadig større foragt for de grundlæggende principper i folkeretten. Ydermere har enkelte normer, ja faktisk næsten hele retssystemet i en enkelt stat, først og fremmest selvfølgelig USA's retssystem, overskredet sine nationale grænser på alle områder: både i økonomi og politik og på det humanitære områ- de påtvinges det andre stater. Hvem kan lide det? Hvem kan lide det?

I internationale anliggender ses der stadig oftere en stræben efter at løse dette eller hint spørgsmål med udgangspunkt i den såkaldte politiske formålstjenlighed på grundlag af de aktuelle politiske konjunkturer.

Og det er naturligvis yderst farligt. Og det fører til, at ingen føler sig i sikkerhed. Fordi ingen kan søge beskyttelse i folkeretten som bag en mur. En sådan politik er naturligvis katalysator for et våbenkapløb.

Magtfaktorens dominans nærer uundgåeligt en række landes hang til at besidde masseødelæggelsesvåben. Desuden er der dukket principielt nye trusler op, som man også kendte til tidligere, men som i dag får global karakter, nemlig fx terrorismen.

Jeg er overbevist om, at vi er kommet til det afgørende øjeblik, hvor vi alvorligt må overveje hele den globale sikkerhedsarkitektur.

Og her må vi begynde med at søge efter en fornuftig balance mellem interesserne hos alle deltagere i den internationale dialog. Især nu, hvor 'det internationale landskab' forandrer sig så mærkbart og så hurtigt - forandrer sig i kraft af en dynamisk udvikling i en hel række stater og regioner.

Fru forbundskansleren var inde på dette. Indiens og Kinas samlede BNP målt i købekraftspariteter er allerede større end USA's. Det tilsva- 
rende BNP for BRIK-landene - Brasilien, Rusland, Indien og Kina overstiger EU's samlede BNP. Og eksperterne skønner, at denne forskel kun vil blive større i et overskueligt historisk perspektiv.

Der er ingen grund til at betvivle, at de nye globale vækstcentres $ø$ konomiske potentiale uundgåeligt vil blive konverteret til politisk indflydelse og styrke multipolariteten.

I denne forbindelse får det multilaterale diplomati en væsentlig større rolle. I politik er der intet alternativ til åbenhed, gennemskuelighed og forudsigelighed, og magtanvendelse bør virkelig være en undtagelsesforanstaltning lige så vel som anvendelse af dødsdom i visse staters retssystemer.

I dag kan vi tværtimod se en situation, hvor lande, som forbyder dødsstraf selv for mordere og andre forbrydere, farlige forbrydere, ikke desto mindre ubekymret deltager i militære operationer, som det er svært at betegne som legitime. Men i disse konflikter omkommer mennesker hundreder, tusinder af civile.

Samtidig melder der sig spørgsmålet: Skal vi udeltagende og viljeløst betragte forskellige interne konflikter i de enkelte lande, autoritære regimers og tyranners handlinger og udbredelsen af masseødelæggelsesvåben? Det var faktisk netop det, der lå til grund for det spørgsmål, vores ærede kollega, hr. Lieberman, stillede forbundskansleren. Jeg forstod vel Deres spørgsmål rigtigt (henvendt til Lieberman)? Det er selvfølgelig et alvorligt spørgsmål. Kan vi passivt betragte det, der sker? Jeg vil også prøve at besvare Deres spørgsmål. Selvfølgelig skal vi ikke se passivt til. Selvfølgelig ikke.

Men har vi midler til at modstå disse trusler med? Selvfølgelig har vi det. Det er nok at tænke på den nyeste historie. Er der ikke sket en fredelig overgang til demokrati i vores land? Jo, der er sket en fredelig transformation af det sovjetiske regime - en fredelig transformation! Og af hvilket regime! Med hvilken mængde af våben, herunder atomvåben! Hvorfor skulle vi bombe og skyde nu ved enhver given lejlighed? Forholder det sig virkelig sådan, at vi i en situation, hvor der ikke er nogen trussel om gensidig ødelæggelse, mangler politisk kultur og respekt for demokratiske værdier og for loven?

Jeg er overbevist om, at $\mathrm{FN}$-pagten er den eneste mekanisme, der kan bruges til at træffe beslutninger om brug af militær magt som sidste udvej. Og i denne forbindelse har enten jeg ikke forstået, hvad vores kollega, den italienske forsvarsminister, lige sagde, eller også udtrykte han sig uklart. Jeg hørte i hvert fald, at magtanvendelse kun kan anses for legitim, hvis beslutningen tages i NATO, EU eller FN. Hvis han virkelig mener det, så har han og jeg forskellige opfattelser. Eller jeg har hørt forkert. Magtanvendelse kan kun anses for legitim, hvis beslutnin- 
gen tages på grundlag af og inden for rammerne af FN. Og FN skal ikke erstattes af hverken NATO eller $\mathrm{EU}$. $\mathrm{Og}$ når $\mathrm{FN}$ reelt vil forene det internationale samfunds kræfter, som virkelig kan reagere på begivenheder i de enkelte lande, og når vi skiller os af med foragten for folkeretten, så kan situationen ændre sig. I modsat fald vil det hele ende i en blindgyde, og mængden af alvorlige fejltagelser vil blive øget. I denne forbindelse skal man selvfølgelig arbejde på, at folkeretten får universel karakter såvel i forståelsen som i anvendelsen af dens normer.

Og man må ikke glemme, at en demokratisk fremgangsmåde i politik altid forudsætter diskussion og en omhyggelig udarbejdelse af beslutninger.

Mine damer og herrer!

Den potentielle fare ved en destabilisering af de internationale relationer hænger også sammen med den åbenlyse stagnation på nedrustningsområdet.

Rusland går ind for en genoptagelse af dialogen om dette meget vigtige spørgsmål.

Det er vigtigt at bevare stabiliteten i det folkeretlige grundlag for nedrustningen og i den forbindelse at sikre kontinuiteten i forløbet af atomvåbenreduktionerne.

Vi har aftalt med USA at reducere vores atomvåben på strategiske fremføringsmidler til 1.700-2.000 atomsprænghoveder inden 31 . december 2012. Rusland har til hen- sigt nøje at overholde de forpligtelser, det har påtaget sig. Vi håber, at også vores partnere vil handle lige så gennemskueligt og ikke lægge et par hundrede overflødige atomsprænghoveder til side for alle tilfældes skyld 'til vanskelige tider'. Og hvis USA's nye forsvarsminister vil erklære for os her i dag, at USA ikke vil skjule disse overflødige sprænghoveder i depoter, 'under hovedpuden' eller 'under tæppet', så vil jeg foreslå, at alle rejser sig og hilser dette velkomment. Det ville være en meget vigtig erklæring.

Rusland overholder nøje og vil også i fremtiden nøje overholde Ikke-spredningstraktaten og det multilaterale kontrolregime for missilteknologier. De principper, der er nedlagt i disse dokumenter, har universel karakter.

I denne forbindelse vil jeg gerne minde om, at USSR og USA $\mathrm{i}$ 1980'erne undertegnede en aftale om at destruere en hel klasse mellem- og kortdistancemissiler, men dette dokument fik ikke universel karakter.

I dag har en hel række lande sådanne missiler: Den Koreanske Folke-Demokratiske Republik, Republikken Korea, Indien, Iran, Pakistan og Israel. Mange andre stater i verden er ved at udvikle disse systemer og planlægger at lade dem indgå $\mathrm{i}$ deres arsenaler. Og kun USA og Rusland er forpligtet til ikke at skabe sådanne våbensystemer.

Det er klart, at vi under disse om- 
stændigheder må gøre os overvejelser om, hvordan vi skal garantere vores egen sikkerhed.

Samtidig skal man ikke tillade fremkomsten af nye destabiliserende højteknologiske våbentyper - for ikke at tale om foranstaltninger til at afværge nye former for konfrontation, især i rummet. 'Stjernekrige' er som bekendte ikke længere science fiction, men en realitet. Allerede i midten af 80'erne gennemførte vores amerikanske partnere nedskydning af en af deres egne satellitter.

Efter Ruslands opfattelse kan en militarisering af rummet få uforudsigelige følger for verdenssamfundet og føre til intet mindre end begyndelsen på en ny atomalder. Og vi har flere gange fremsat initiativer med henblik på at forhindre brugen af våben i rummet.

I dag vil jeg gerne informere Dem om, at vi har udarbejdet et udkast til en aftale om forhindring af anbringelse af våben i det ydre rum. I nær fremtid vil den blive sendt til vores partnere som et officielt forslag. Lad os samarbejde om dette.

Vi kan heller ikke andet end blive foruroligede over planerne om at opstille elementer af et missilforsvarssystem i Europa. Hvem ønsker endnu et skridt i det i dette tilfælde uundgåelige våbenkapløb? Jeg tvivler meget på, at europæerne selv gør.

Der er ikke ét af de såkaldte 'problemlande', der har missiler med en rækkevidde på $5.000-8.000 \mathrm{~km}$, der reelt kan true Europa. Og i en over- skuelig fremtid og i et overskueligt perspektiv vil der ikke komme nogen, ja det forudses ikke engang. Og en hypotetisk affyring af fx et nordkoreansk missil mod USA's territorium hen over Vesteuropa er i klar modstrid med ballistikkens love. Som vi siger i Rusland, så ville det være det samme som "at prøve at nå venstre øre med højre hånd”.

Og nu jeg er her i Tyskland, vil jeg ikke undlade at minde om CFE-traktatens krisetilstand.

Den adapterede CFE-traktat blev undertegnet i 1999. Den tog hensyn til den nye geopolitiske realitet - opløsningen af Warszawablokken. Siden da er der gået syv år, og kun fire stater har ratificeret dette dokument, inklusive Den Russiske Føderation.

NATO-landene har åbent erklæret, at de ikke vil ratificere traktaten, herunder bestemmelserne om flankebegrænsninger (om placering af et vist antal væbnede styrker på flankerne), før Rusland har fjernet sine baser fra Georgien og Moldova. Vores tropper er ved at blive trukket ud af Georgien, endda i forceret tempo. Disse problemer har vi løst med vore georgiske kolleger, og det er alle bekendt. I Moldova er der stadig en gruppe på 1.500 soldater, som udfører fredsskabende funktioner og bevogter ammunitionsdepoter fra sovjettiden. Og dette spørgsmål drøfter vi konstant med hr. Solana - han kender vores holdning. Vi er rede til at arbejde videre i denne retning. 
Men hvad foregår der samtidigt? Samtidigt etableres i Bulgarien og Rumænien de såkaldte lette amerikanske fremskudte baser med 5.000 mand i hver. Der sker altså det, at NATO rykker sine forreste styrker frem til vores statsgrænser, mens vi nøje overholder CFE-traktaten og ikke på nogen måde reagerer på disse handlinger.

Jeg tænker, at NATOs udvidelse åbenbart ikke har noget at gøre med moderniseringen af selve alliancen eller med betryggelsen af sikkerheden i Europa. Tværtimod er det en meget provokerende faktor, der sænker niveauet for gensidig tillid. Og vi er i vores gode ret til at spørge åbent: Hvem er denne udvidelse rettet imod? Og hvad er der blevet af de forsikringer, som de vestlige partnere fremsatte efter opløsningen af Warszawapagten? Hvor er de erklæringer nu? Dem er der ingen, der husker. Men i dette forum vil jeg tillade mig at minde om, hvad der blev sagt. Jeg vil gerne anføre et citat fra en tale, som NATOs generalsekretær, hr. Wörner, holdt i Bruxelles den 17. maj 1990. Han sagde dengang: "Selve den kendsgerning, at vi er rede til ikke at placere NATO-styrker uden for Forbundsrepublikken Tysklands territorium giver Sovjetunionen faste sikkerhedsgarantier." Hvor er de garantier?

Berlinmurens sten og betonblokke er for længst blevet fordelt som souvenirs. Men man må ikke glem- me, at murens fald også blev muligt takket være det historiske valg, som bl.a. vores folk, Ruslands folk, foretog, et valg til fordel for demokrati og frihed, åbenhed og oprigtigt partnerskab med alle medlemmer af den store europæiske familie.

$\mathrm{Nu}$ forsøger man at påtvinge os nye skillelinjer og mure - ganske vist kun virtuelle, men dog skillelinjer, der gennemskærer vores fælles kontinent. Skal der virkelig igen bruges mange år og årtier såvel som flere generationer af politikere til 'at nedrive' og 'demontere' disse nye mure?

Ærede damer og herrer!

Vi går også utvetydigt ind for en styrkelse af ikke-spredningsregimet. Det foreliggende folkeretlige grundlag gør det muligt at udvikle teknologier til fremstilling af atombrændsel til fredelige formål. Og mange lande ønsker med al god grund at skabe deres egen atomenergi som grundlag for deres energiuafhængighed. Men vi forstår også, at disse teknologier hurtigt kan omstilles til fremstilling af våben.

Det skaber alvorlig international spænding. Et klart eksempel herpå er situationen med det iranske atomprogram. Hvis det internationale samfund ikke finder en fornuftig løsning på denne interessekonflikt, vil verden også fremover blive rystet af lignende destabiliserende kriser, fordi der er flere tærskellande end Iran, og det ved De og vi godt. Vi vil hele tiden støde på trus- 
len om spredning af masseødelæggelsesvåben.

Sidste år tog Rusland initiativ til at oprette internationale centre for berigelse af uran. Vi er åbne overfor, at sådanne centre oprettes ikke kun $\mathrm{i}$ Rusland, men også i andre lande, hvor der findes fredelig atomenergi på legitimt grundlag. Stater, der ønsker at udvikle atomenergi, kunne garantere, at de ville modtage brændsel ved direkte deltagelse i disse centres arbejde - naturligvis under streng kontrol fra Det Internationale Atomenergiagentur.

De seneste initiativer, USA's præsident George Bush har taget, stemmer overens med det russiske forslag. Jeg mener, at Rusland og USA objektivt og i samme grad er interesserede $i$ at skærpe regimerne for ikke-spredning af masseødelæggelsesvåben og midler til fremføring af dem. Netop vores lande, der er førende med hensyn til atom- og missilpotentiale, bør føre an i udarbejdelsen af nye, strengere foranstaltninger på ikke-spredningsområdet. Rusland er rede til det arbejde. Vi fører konsultationer med vores amerikanske venner.

Generelt bør det dreje sig om at skabe et helt system af politiske incitamenter og økonomiske stimuli, hvorved staterne ikke ville være interesserede i at skabe egne kapaciteter til fremstilling af atombrændsel, men ville have mulighed for at udvikle atomenergi og styrke deres energipotentiale.
I denne forbindelse vil jeg se lidt nærmere på det internationale energisamarbejde. Fru forbundskansleren berørte også dette emne om end kort. På energiområdet agter Rusland at skabe fælles markedsprincipper og gennemskuelige betingelser for alle. Det er klart, at prisen på energi skal bestemmes af markedet og ikke være genstand for politiske spekulationer, økonomisk påvirkning eller afpresning.

Vi er åbne for samarbejde. Udenlandske selskaber deltager i vores største energiprojekter. Ifølge forskellige skøn finansieres op til $26 \%$ af olieudvindingen i Rusland - læg lige mærke til dette tal - op til $26 \%$ af olieudvindingen i Rusland af udenlandsk kapital. Prøv, prøv at give mig et eksempel på en lignende bred tilstedeværelse af russiske forretningsfolk i nøglebrancherne i de vestlige staters økonomi. Sådanne eksempler findes ikke! Det gør de ikke.

Jeg vil også minde om forholdet mellem de investeringer, der kommer til Rusland, og dem, der går fra Rusland til andre lande i verden. Forholdet er cirka 15 til 1 . Her har De et tydeligt eksempel på den russiske $ø$ konomis åbenhed og stabilitet.

Økonomisk sikkerhed er et område, hvor alle skal følge samme principper. Vi er rede til ærlig konkurrence.

Det skabes der stadig større muligheder for i den russiske økonomi. Eksperter og vores udenlandske 
partnere bedømmer denne dynamik objektivt. Således blev Ruslands kreditværdighed i OECD forhøjet for nylig: vores land gik fra fjerde risikogruppe op i tredje. Og jeg vil gerne benytte mig af lejligheden til her i München at takke vores tyske kolleger for medvirken til denne beslutning.

Som De ved, er Ruslands tilslutningsproces til WTO inde i slutfasen. Jeg vil bemærke, at vi under de lange, vanskelige forhandlinger flere gange har hørt ord om ytringsfrihed, frihandel og lige muligheder, men af en eller anden grund kun med reference til det russiske marked.

Der er endnu et vigtigt emne, som har direkte indflydelse på den globale sikkerhed. I dag tales der meget om bekæmpelse af fattigdommen. Hvad sker der i virkeligheden på dette område? På den ene side bevilges der finansielle ressourcer - og undertiden store finansielle ressourcer - til hjælpeprogrammer for de fattigste lande. Men ærligt talt - og det ved mange her - så går de ofte til 'udvikling' af donorlandenes egne selskaber. Men på den anden side bevares samtidigt subsidierne til landbruget i de udviklede lande, og adgangen til højteknologier begrænses for udenforstående.

Lad os kalde tingene ved deres rette navn: Der sker det, at med den ene hånd giver man 'velgørenhedshjælp', og med den anden opretholder man ikke alene den økonomiske tilbageståenhed, men høster også profitten heraf. Den sociale spænding, der opstår i disse depressive regioner, fører uvægerligt til voksende radikalisme og ekstremisme og nærer terrorisme og lokale konflikter. Og hvis alt dette oven i købet foregår fx i Mellemøsten, hvor man i stigende grad opfatter omverdenen som uretfærdig, så opstår der en risiko for global destabilisering.

Det er klart, at de ledende lande i verden bør se denne trussel. Og at de derfor skal skabe et mere demokratisk og retfærdigt system af økonomiske relationer i verden - et system, der giver alle en chance og en mulighed for udvikling.

Når man taler på en sikkerhedskonference, ærede damer og herrer, kan man ikke forbigå Organisationen for Sikkerhed og Samarbejde i Europas (OSCE's) virke i tavshed. Som bekendt blev den oprettet for at undersøge alle - jeg understreger dette - alle, alle aspekter af sikkerheden: de militær-politiske, økonomiske og humanitære og sammenhængen mellem disse.

Hvad ser vi i dag i praksis? Vi ser, at denne balance er klart ødelagt. OSCE forsøges gjort til et vulgært instrument til sikring af et lands eller en gruppe landes udenrigspolitiske interesser i forhold til andre lande. Og denne opgave har man 'skræddersyet' OSCE's bureaukratiske apparat til, som absolut ikke har nogen som helst forbindelse med grundlæggerstaterne. Procedurerne 
for beslutningstagning og anvendelse af de såkaldte ngo'er er 'skræddersyet' til denne opgave. Ja, formelt er ngo'erne uafhængige, men de er målrettet finansierede og altså kontrollerede.

I henhold til de grundlæggende dokumenter skal OSCE på det humanitære område yde bistand til medlemslandene på disses anmodning med henblik på overholdelse af de internationale menneskerettighedsnormer. Det er en vigtig opgave. Den støtter vi. Men det betyder altså ikke indblanding i andre landes indre anliggender og endnu mindre, at man skal påtvinge disse stater retningslinjer for, hvordan de skal leve og udvikle sig.

Det er klart, at en sådan indblanding bestemt ikke bidrager til udvikling af ægte demokratiske stater, men tværtimod gør dem afhængige og som følge heraf ustabile i politisk og økonomisk henseende.

Vi forventer, at OSCE vil holde sig til sine umiddelbare opgaver og bygge sine relationer med suveræne stater på grundlag af respekt, tillid og gennemskuelighed.

Ærede damer og herrer!

Til afslutning vil jeg gerne sige følgende. Vi hører meget ofte, og jeg personligt hører meget ofte opfordringer til Rusland fra vores partnere, bl.a. også fra vores europæiske partnere, om at spille en mere og mere aktiv rolle i verdens anliggender. I denne forbindelse vil jeg tillade mig at gøre en lille bemærkning.
Det er næppe nødvendigt at anspore og tilskynde os til det. Rusland er et land med en mere end tusindårig historie, og det har praktisk talt altid nydt det privilegium at føre en uafhængig udenrigspolitik.

Vi vil ikke ændre denne tradition i dag. Samtidig kan vi udmærket se, hvordan verden har forandret sig, og vi foretager en realistisk vurdering af vores egne muligheder og vores eget potentiale. $\mathrm{Og}$ vi vil selvfølgelig gerne have at gøre med ansvarlige og selvstændige partnere, som vi kan samarbejde med i opbygningen af en retfærdig og demokratisk verdensorden, der kan betrygge sikkerhed og opblomstring for alle og ikke kun for nogle få udvalgte.

Tak for opmærksomheden.

H. Teltschik: Hjertelig tak for Deres meget vigtige indlæg. Der lød nye temaer, herunder spørgsmålet om den globale arkitektur, som ikke har stået i forgrunden i de senere år; nedrustning, våbenkontrol, spørgsmålet om forholdet mellem den nordatlantiske alliance og Rusland, samarbejde på det teknologiske område.

Der er stadig en hel række spørgsmål, og præsidenten er rede til at besvare dem.

Spørgsmål: Ærede hr. præsident, mange tak for Deres indlæg. Jeg vil gerne understrege, at vi i den tyske Forbundsdag er helt klar over, hvor vigtig Rusland er som Europas partner, og hvor vigtig den rolle er, som 
De spiller. Det nævnte forbundskansleren i sit indlæg.

Jeg vil gerne med udgangspunkt i mine egne erfaringer berøre to punkter i Deres tale. Det er for det første vurderingen af NATO og dens udvidelse, som De finder farlig for Rusland. Vil De erkende, at udvidelsen faktisk ikke er en udvidelse, men at der er tale om, at demokratiske stater selv beslutter at gå denne vej? Og at NATO har svært ved at optage stater, som ikke udviser en sådan beredvillighed? De kunne erkende, at østgrænserne takket være NATO er blevet mere pålidelige og sikre. Hvorfor er De bange for demokrati? Jeg er overbevist om, at kun demokratiske stater kan blive medlemmer af NATO. Det stabiliserer naboerne.

Og så med hensyn til det, der foregår i Deres land. Anna Politkovskaja blev myrdet; det er et symbol. Man kan sige, at dette vedrører mange journalister, skaber al mulig frygt, og at loven om ngo'erne også vækker bekymring.

Spørgsmål: Jeg forstår udmærket Deres bemærkning om ikke-spredning. Især i slutningen af den Kolde Krig var vi vidner til en reduktion af deployeringen af atomvåben, men også til en vækst i terrorisme. Atomare materialer bør beskyttes godt mod terrorister.

Spørgsmål: Jeg vil godt vende tilbage til et spørgsmål, forbundskansleren fik stillet. Hvad kommer der til at ske i Kosovo og Serbien? Hvordan vurderer De M. Ahtisaari? Hvordan vil Rusland påvirke løsningen af dette problem?

Spørgsmål: Kan De kommentere de erfaringer, russisk militært personel har høstet i Tjetjenien. Og med hensyn til Deres bemærkninger om energi: De redegjorde kort for den markedsrolle, energi spiller i politik. EU er interesseret $i$ at indgå en partnerskabsaftale for dermed at fastlægge principperne på det politiske område. Er De rede til at sikre pålidelige energileverancer og lade det indgå i aftalen?

Spørgsmål: Hr. præsident, Deres tale var oprigtig og åbenhjertig. Jeg håber, at De vil forstå mit åbenhjertige og direkte spørgsmål. I 90'erne hjalp russiske eksperter aktivt Iran med at udvikle missilteknologier. $\mathrm{Nu}$ har Iran avancerede mellem- og langdistancemissiler, som giver det mulighed for at rette et angreb mod Rusland og en del af Europa. De arbejder også på at placere atomsprænghoveder på disse missiler. Deres land har gjort sig anstrengelser for at forhandle med Iran om dette spørgsmål og har støttet FN's Sikkerhedsråds resolution om ikke at give Iran lov til at føre en sådan politik.

Mit spørgsmål går ud på følgende: Hvad vil Rusland gøre - gennem FN eller på anden vis - for at standse disse meget alvorlige begivenheder $\mathrm{i}$ Iran?

Spørgsmål: Jeg er sikker på, at historikerne ikke en skønne dag vil skrive, at den anden kolde krig blev erklæret under vores konference. 
Men det kunne de godt. De sagde, at der også skal lægges pres på Iran og gives positive impulser. Er det ikke rigtigt, at Rusland forhindrer et stærkt pres i form af sanktioner og for det andet, hvad angår våbenleverancer, opmuntrer Iran ikke mindst, efter at disse våben er dukket op i Libanon og Gaza? Hvilket kommentarer har De til det?

Spørgsmål: Jeg forstår Deres oprigtighed og håber, at De også accepterer vores oprigtighed. For det første om våbenkontrol. Hvem har brug for et nyt våbenkapløb? Jeg vil gerne påpege, at USA i over to årtier ikke har udviklet nye strategiske våben, mens De for nylig har afprøvet missilet 'Topol-M', som allerede er placeret i siloer og på mobile installationer. De har kritiseret USA for ensidige handlinger og to gange sagt, at militære aktioner kun kan være lovlige, hvis de er godkendt af FN. USA gennemfører militære aktioner i Irak og Afghanistan i henhold til FN-beslutninger, og i Kosovo støtter størstedelen af styrkerne den fredsskabende operation i dette land.

Mit spørgsmål lyder: Siger De nu, at Rusland uafhængigt af, hvordan det betragter truslen mod sine internationale interesser, ikke vil indlede kamphandlinger uden FN's godkendelse?

Spørgsmål: De talte om faren ved den unipolære verden, hvor en suveræn træffer beslutninger uden at konsultere andre. I Rusland ser vi efter manges mening en stadig mere unipolær regering, hvor konkurrerende indflydelsescentre er nødt til at følge partilinjen, det være sig Statsdumaen, de regionale ledelser, massemedierne, forretningsverdenen og ngo'erne. Vil en unipolær regering af denne slags være en pålidelig partner, når det drejer sig om energisikkerhed?

Vladimir Putin: Jeg vil først og fremmest gerne takke for disse spørgsmål. Det er meget interessant. Det er trist, at vi har så lidt tid, for jeg ville være glad for at føre en diskussion med hver enkelt af Dem. Det holder jeg meget af, det kan jeg godt lide.

Jeg vil begynde med det sidste spørgsmål om den russiske regerings unipolære karakter. I dag er Den Russiske Føderations Kommunistiske Parti, partiet Forenet Rusland og Det Liberal-Demokratiske Parti og andre politiske kræfter repræsenteret i det russiske parlament, og deres grundlæggende synspunkter adskiller sig principielt fra hinanden. Hvis De ikke er klar over det, så tag en snak med ledelsen af Den Russiske Føderations Kommunistiske Parti og derefter med lederen af vores liberale demokrater, hr. Zjirinovskij. Og så vil De straks se forskellen. Hvis De ikke kan se den nu, så tag en snak med dem. Det er der ingen problemer $\mathrm{i}-$ tag bare til Moskva og tal med dem.

Og så hvad angår vores fremtidsplaner. Vi kunne godt tænke os at 
have et modent politisk system, et flerpartisystem med ansvarlige politikere, som kan forudse landets udvikling og handle ansvarligt ikke alene under valgene og efter dem, men også i et længere historisk perspektiv. Det er det, vi vil bestræbe os på. Men det system vil selvfølgelig blive et flerpartisystem. Alt, hvad vi gør i selve landet, bl.a. vedrørende ændring af valgproceduren til Statsdumaen, Ruslands parlament, går ud på at styrke flerpartisystemet i landet.

Så til spørgsmålet om, hvorvidt vores regering er i stand til at handle ansvarligt ved løsning af energileveranceproblemer og betryggelse af energisikkerheden. Selvfølgelig er den det. Oven i købet er alt det, vi har gjort hidtil og gør nu, rettet mod at nå kun ét mål: at omsætte alle vore relationer med forbrugerne af vores kulbrinter og transitlandene til gennemskuelige markedsprincipper og til langtidskontrakter.

Jeg vil minde Dem om - og her over for mig sidder min kollega, Ukraines præsident, og han ved det lige så vel som jeg - nemlig, at indtil sidste år, hvor han og jeg i en vanskelig diskussion traf visse beslutninger, har leverancerne af vores energi, først og fremmest gas, til Europa i 15 år været afhængige af, om Ukraine og Rusland kunne enes om betingelserne og priserne for leverancerne af vores gas til Ukraine selv. Og hvis de ikke enedes, så ville alle europæiske forbrugere sidde uden gas. Kan De lide den situation? Det tror jeg ikke. Og trods alle skandalerne og alt det andet, forsvar af interesser, meningsforskelle osv. kunne præsident Jusjtjenko og jeg indgå en aftale. Jeg mener, at han traf en ansvarlig, helt rigtig og absolut markedsorienteret beslutning: Vi undertegnede separate kontrakter om leverance af vores gas til Ukraine og om transit til Europa for de næste fem år. De burde takke os, både os og Ukraine, for den beslutning. $\mathrm{Og}$ tak for Deres spørgsmål. Det var et godt spørgsmål.

Jeg skulle hellere have besvaret Deres spørgsmål med det samme. Vores vurdering af NATOs udvidelse mod øst. Jeg har allerede nævnt de garantier, som vi fik, og som ikke overholdes i dag. Finder De det normalt $\mathrm{i}$ internationale anliggender? Men glem dem, de garantier! Hvad angår demokrati og NATOs udvidelse. NATO er ikke en universel organisation til forskel fra FN. Det er først og fremmest en militær-politisk blok - militær-politisk! Betryggelsen af egen sikkerhed er naturligvis enhver suveræn stats prærogativ. Det betvivler vi ikke. Det har vi såmænd ikke noget imod. Men hvorfor skal den militære infrastruktur absolut rykkes frem til vores grænser ved udvidelsen? Er der nogen, der kan svare os på det? Har udvidelsen af den militære infrastruktur da noget at gøre med overvindelsen af de aktuelle globale trusler? Hvis vi nu skulle nævne den største trussel i dag - 
både for os og for USA og Europa, hvad er det så for en trussel? Det er terrorismen og kampen mod den.

Er der brug for Rusland i kampen mod terrorismen? Selvfølgelig! Er der brug for Indien i kampen mod terrorismen? Selvfølgelig! Men de er ikke med i NATO, og det er andre lande heller ikke. Vi kan imidlertid kun arbejde effektivt med denne problematik ved at forene vores anstrengelser. Så udvidelse af den militære infrastruktur og en fremrykning af den til vores grænser har ikke noget at gøre med de enkelte staters demokratiske valg. Jeg vil bede Dem om ikke at blande disse to begreber.

Jeg har skrevet så grimme kragetæer her, at jeg ikke selv kan læse, hvad jeg har skrevet. Derfor vil jeg svare på det, jeg selv kan læse, og hvis der er noget, jeg ikke får svaret på, må De minde mig om Deres spørgsmål.

Hvad vil der ske med Kosovo og Serbien? Det kan kun kosovarerne og serberne selv vide. Og lad os ikke bestemme for dem, hvordan de skal indrette deres liv. Man skal ikke prøve at spille Gud og løse alle problemer for alle folkeslag. Vi kan kun skabe de nødvendige betingelser og hjælpe folk med at klare deres problemer - skabe betingelser og optræde som garanter for visse aftaler. Men man skal ikke påtvinge dem disse aftaler. Ellers driver vi situationen ind i en blindgyde. Hvis nogle af deltagerne i denne meget kompli- cerede proces mellem disse folkeslag føler sig krænkede og ydmygede, så vil det trække ud i århundreder. Vi vil kun drive problemet ind $\mathrm{i}$ en blindgyde.

Hvad er vores holdning? Vores holdning går ud på, at vi vil holde os til netop dette princip. Og hvis vi ser, at en af partnerne er klart utilfreds med de foreslåede metoder til at løse situationen, vil vi ikke støtte en sådan beslutning.

Jeg forstod ikke rigtigt, hvad De tænkte på, da De spurgte om vores soldaters erfaringer i Tjetjenien. Deres erfaringer er ikke særlig rare, men store. Hvis De er interesseret i den generelle situation i Tjetjenien, så kan jeg fortælle Dem, at der nu er valgt et parlament, der er valgt en præsident, og at regeringen fungerer. Alle magt- og forvaltningsorganer er oprettet. Praktisk talt alle Tjetjeniens politiske kræfter er inddraget $i$ arbejdet i republikken. Jeg kan $\mathrm{fx}$ fortælle, at den tidligere forsvarsminister i A. Maskhadovs regering nu er medlem af parlamentet i Tjetjenien. Og vi har taget en hel række beslutninger, der gør det muligt for tidligere oprørere at vende tilbage ikke alene til et normalt liv, men også til det politiske liv i republikken. Så vi foretrækker i dag at handle dér med politiske og økonomiske midler efter at have overdraget betryggelsen af sikkerheden næsten $100 \%$ til det tjetjenske folk selv. Ordensmagtens organer, som er opstillet dér, består næsten $100 \%$ af loka- 
le borgere, af dem, der bor permanent i Tjetjenien - af tjetjenere.

Hvad angår Libanon, forstod jeg heller ikke rigtigt, hvad De mente. Men en bekræftelse af, at den velkendte situation er opstået, sådan som jeg ridsede den op, er den omstændighed, at vi har sendt vores militære bygningsarbejdere til Libanon for at genopbygge de broer og den infrastruktur, som blev ødelagt under konflikten med Israel. Og disse bygningsarbejdere blev beskyttet af enheder, der kun bestod af militært personel fra Tjetjenien og etniske tjetjenere. Vi gik ud fra, at vores soldater skulle arbejde i områder, der er befolket med muslimer, og hvis det kontingent, der skulle beskytte soldaterne, også var muslimer, så ville det være udmærket. Og vi tog ikke fejl. Lokalbefolkningen tog virkelig meget varmt imod vores militære bygningsarbejdere.

$\mathrm{Nu}$ til energiaftalen med EU - har jeg forstået spørgsmålet rigtigt? Vi har mange gange sagt, at vi ikke har noget imod at afstemme principperne for vores relationer med EU på energiområdet. Så meget desto mere som de principper, der er nedlagt i Energicharteret, i det store og hele er acceptable. Men selve charteret er vi ikke så glade for. Det realiseres nemlig hverken af os eller af vores europæiske partnere. Jeg kan bare minde om, at markedet for atomare materialer stadig er lukket for os. Det er der ingen, der har åbnet for os.
Der er også andre momenter, som jeg bare ikke vil samle opmærksomheden om nu, men selve principperne anvendes af os bl.a. også i arbejdet med de tyske selskaber. Jeg vil godt minde om den handel, der er indgået mellem Gazprom og selskabet BASF. Det er faktisk et bytte af aktiver. Sådan er vi også rede til at handle i fremtiden. Det er vi.

Men i hvert konkret tilfælde må vi forstå, hvad vi giver bort, hvad vores partnere giver bort, lave beregninger og foretage en uafhængig international ekspertvurdering og træffe en beslutning. Vi er rede til det arbejde. Vi har for nylig gjort det samme med vores italienske partnere, med selskabet ENI. Vi har ikke alene undertegnet en aftale med dem om leverancer til 2035, men så vidt jeg ved, drejer det sig også om bytte af aktiver. $\mathrm{Nu}$ undersøger vi den samme form for samarbejde med vores ukrainske venner. Processen er i gang.

Skal disse principper indgå i en mulig fremtidig grundlæggende akt mellem Rusland og EU? Det kan der være forskellige meninger om. Men jeg mener, at de ikke skal, for ud over energi er der også andre samarbejdsområder i vores relationer med EU: både landbrug, højteknologi og transport. Og det er alt sammen meget vigtigt og meget interessant. $\mathrm{Vi}$ kan ikke få det hele med i en grundlæggende akt, der skal være et rammedokument. Men De vil måske have, at vi kun skal medtage det, 
som De har brug for, og udelade det, som vi har brug for? Lad os dog diskutere ærligt med hinanden og træffe gensidigt fordelagtige beslutninger.

"I 1990'erne ydede Rusland Iran hjælp til at udvikle missilteknologi." Det var vist Dem, der stillede mig det spørgsmål. "I dag vil iranerne gerne forsyne disse missiler med atomsprænghoveder, og de har missiler, der kan nå Europa. Hvad vil Rusland stille op med det iranske atomprogram?" Er det rigtigt forstået? For det første har jeg ingen oplysninger om, at Rusland i 90'erne ydede Iran hjælp til at udvikle egne missilteknologier. Det var andre lande, der arbejdede meget aktivt på det. Og teknologierne ankom ad forskellige kanaler. Det har vi vidnesbyrd om. I sin tid videregav jeg dem direkte til USA's præsident. Der kommer også teknologier fra Europa og fra asiatiske lande.

Så Rusland kan ikke lastes for noget her. Jeg forsikrer Dem. Rusland er mindst af alle indblandet her. Mindst af alle. Hvis det overhovedet er indblandet. Dengang arbejdede jeg stadig i Sankt Petersborg, men det havde vi ikke noget med at gøre. Det kan jeg forsikre Dem om. Men De ved, der kunne være foregået noget i forretningsverdenen. Vi uddannede specialister på institutter osv. Og på anmodning og i henhold til informationer fra vores amerikanske partnere reagerede vi barsk på det. Lige med det samme og barsk.
Men vi så ikke nogen reaktioner fra vores andre partnere, herunder fra Europa. Jeg ved ikke, om De ved det eller ej, men De burde vide det: der kommer stadig militært materiel og specialudstyr fra USA. Stadigvæk. Fra beholdningerne i de væbnede styrker, fra Pentagon, kommer der stadig reservedele til F-14-flyene. Så vidt jeg ved, foretages der en undersøgelse i USA i denne anledning. Selvom denne undersøgelse pågår, har de pågrebet disse reservedele ved grænsen og sendt dem tilbage, og noget senere har man ifølge de oplysninger, jeg har, og hvis de ikke er rigtige, så må De kontrollere dem, pågrebet det samme fragtgods igen. Endda med en seddel på, hvor der stod 'reelt bevis'.

De ved, denne strøm er virkelig svær at stoppe. Vi må være fælles om det.

Hvad angår spørgsmålet om, hvorvidt Iran har missiler, som kan true Europa. De tager fejl. I dag har Iran - her er hr. Gates (Robert Gates, forsvarsminister, USA), som sikkert ved det bedre end jeg, og vores forsvarsminister - Iran har i dag missiler med en rækkevidde på $2.000 \mathrm{~km}$.

Sergej Ivanov: (Forsvarsminister, Rusland ) 1.600-1.700 km.

Vladimir Putin: $1.600-1.700 \mathrm{~km}$. Ikke mere. Regn ud, hvor mange kilometer der er fra Irans grænse til München. Iran har ikke sådan nogen missiler. De planlægger kun at udvikle nogle med en rækkevidde på $2.400 \mathrm{~km}$. Og det vides ikke, om 
de har teknologi til at gøre det. Og med hensyn til 4.000, 5.000 eller $6.000 \mathrm{~km}$ så tror jeg, det simpelthen kræver en anden økonomi. Så det er i det hele taget ikke ret sandsynligt. Og Iran truer ikke Europa. Hvad angår det forhold, at de vil bruge atomsprænghoveder, så har vi ikke nogen oplysninger om det.

Nordkorea har gennemført en test af kernevåben. Iranerne fortæller os hele tiden, at deres atomprogram har en fredelig karakter. Men jeg er enig med Dem i, at det internationale samfund nærer bekymringer med hensyn til karakteren og kvaliteten af Irans atomprogrammer. Og hr. El Baradei (generaldirektør for Det Internationale Atomenergiagentur (IAEA)) har for nylig formuleret disse bekymringer i seks eller syv punkter, tror jeg. Og her er jeg enig med Dem. Jeg kan ikke forstå, hvorfor den iranske part endnu ikke har reageret på en positiv og konstruktiv måde på disse bekymringer og El Baradeis forslag til at bortvejre dem. Det kan jeg ikke forstå, lige så lidt som De kan.

Hvad skal vi stille op? Jeg mener, at vi skal væbne os med tålmodighed og arbejde omhyggeligt. Det vil være rigtigt, og vi skal skabe stimuli og vise den iranske ledelse, at samarbejde med det internationale samfund er langt bedre end konfrontation.

$\mathrm{Og}$ så igen om leverancerne af våben til Iran. De ved, at der har været mere snak om det end leverancer. Vores militær-tekniske samarbej- de med Iran er minimalt. Simpelthen minimalt. Jeg ved ikke, hvilke tal det opgøres til. I det hele taget leverer vi langt færre våben til Mellemøsten end andre lande, herunder USA. Langt færre - der er ingen sammenligning. For nylig leverede vi luftværnssystemer til Iran - det er sandt - med en rækkevidde på ca. $30-50 \mathrm{~km}$. Det er rigtigt. Hvorfor gjorde vi det? Det kan jeg forklare. Vi gjorde det, for at Iran ikke skulle føle sig trængt op i et hjørne. For at det ikke skulle føle sig omringet af fjender, men forstå, at det har en kommunikationskanal, at det har venner, det kan stole på. Vi regner stærkt med, at den iranske part vil forstå og høre vores signaler.

Med hensyn til vores våben i Libanon og Gaza-striben. Jeg har overhovedet ikke hørt om, at vi skulle have våben i Gaza-striben. Det har jeg ikke set noget til. Kalasjnikov-geværet er det mest udbredte skydevåben i verden. Det findes sikkert overalt. Der er sikkert også stadig Kalasjnikov-geværer i brug i Tyskland, nogle der ikke er destrueret. Det er $100 \%$ sikkert.

I Libanon er der. Dér har man faktisk observeret kasser til vores panserværnssystemer. Det er rigtigt. Det meddelte vores israelske partner mig med det samme. Vi har foretaget en grundig undersøgelse af, hvad der er foregået. Og vi fandt ud af, at disse systemer var blevet efterladt på libanesisk territorium, efter at den syriske hær havde forladt lan- 
det. Vi har arbejdet med vores syriske partnere og gjort det klart, at det fortsatte militær-tekniske samarbejde med Syrien skal foregå på betingelser, der udelukker muligheden af, at våben falder i andre hænder end dem, de er bestemt til. Der er udarbejdet et sådant system. Vi er bl.a. enedes om et system med mulige depotinspektioner på et hvilket som helst tidspunkt, der måtte passe de russiske specialister. Inspektioner på depoter efter leverancer af vores systemer til Syrien.

"USA udvikler ikke strategiske våben, men det $g ø r$ Rusland. Vil Rusland anvende magt uden FNsanktion i fremtiden? Rusland er ved at udvikle et system af strategiske våben.”

Dejligt spørgsmål, fint! Jeg er Dem meget taknemlig for det. Det giver mig mulighed for at påpege det vigtigste af det, der foregår. Hvad skyldes det i de seneste årtier, at vi kan sige, at der var konfrontation mellem to supermagter og systemer, men det kom ikke til storkrig? Det skyldes magtbalancen mellem disse supermagter. Der var balance, og der var en frygt for gensidig ødelæggelse. Og i den sidste tid var den ene part bange for at tage et skridt for meget uden at rådføre sig med den anden part. Det var selvfølgelig en skrøbelig og skræmmende fred. Men den var ret sikker, kan vi se i dag. I dag ser freden ikke ud til at være så sikker.

Ja, USA udvikler angiveligt ikke offensive våben. I hvert fald ved of- fentligheden ikke noget om det. De er såmænd nok ved at udvikle dem. Men det vil vi ikke en gang spørge om nu. Vi ved, at udviklingen er i gang. Men vi lader, som om vi ikke ved det, så det gør de altså ikke. Men hvad ved vi? At USA aktivt er ved at udvikle og indføre et missilforsvarssystem. Ja, i dag er det ineffektivt, og vi ved ikke rigtigt, om det nogensinde bliver effektivt. Men teoretisk skabes det til dette formål.

Vi kan altså hypotetisk gå ud fra, at der vil komme et tidspunkt, hvor en mulig trussel fra vores atomstyrker vil blive fuldstændigt neutraliseret. Altså Ruslands nuværende atomstyrker. Hvis det forholder sig sådan, så betyder det, at magtbalancen vil blive helt ødelagt, og at den ene af parterne vil kunne føle sig helt sikker og få frie hænder ikke blot i lokale, men også i globale konflikter.

$\mathrm{Nu}$ diskuterer vi med hinanden. Jeg vil ikke mistænke nogen for at være aggressiv. Men systemet af relationer er ligesom matematik. Det har ikke nogen personlig dimension. Og vi skal selvfølgelig reagere på det. Hvordan? Enten ligesom De ved at bygge et missilforsvarssystem til mange milliarder eller under hensyntagen til vores nuværende økonomiske og finansielle muligheder svare asymmetrisk. Så alle kan forstå, at ganske vist er der et missilforsvarssystem, men det er meningsløst i relation til Rusland, fordi vi har våben, som let kan overvinde det. Det er den vej, vi vil følge. Det 
er billigere for os. Men det er på ingen måde rettet mod USA.

Jeg er helt enig med Dem, hvis De siger, at missilforsvarssystemet ikke er rettet mod os, ligesom vores nye våben ikke er rettet mod jer. Her er jeg fuldstændig enig med min kollega og ven - jeg er ikke bange for at bruge dette ord, for trods alle meningsforskelle anser jeg USA's præsident for at være min ven. Han er en retskaffen mand, og jeg ved, at han kan blive kritiseret i USA for alt, der gøres på den internationale arena og i selve landet. Men jeg ved, han er en retskaffen mand, og at man kan tale med ham og indgå aftaler med ham. Når vi taler med hinanden, siger han: "Jeg går ud fra, at Rusland og USA aldrig bliver modstandere og fjender igen." Jeg er enig med ham. Men jeg gentager: her er symmetri og asymmetri, her er ikke noget personligt. Det er simpelthen en kalkule.

Nu med hensyn til, hvorvidt Rusland vil anvende militær magt uden sanktion fra FN. Vi vil altid handle nøje inden for rammerne af folkeretten. Min grunduddannelse er nu engang juridisk, og jeg vil tillade mig at minde både mig selv og mine kolleger om, at der i henhold til FN-pagten kræves sanktioner fra FN's Sikkerhedsråd til at gennemføre fredsskabende operationer. Til at gennemføre fredsskabende operationer. Men i FN-pagten er der også en artikel om ret til selvforsvar. Og her behøves der ikke nogen sanktioner.
Hvad har jeg så glemt?

Spørgsmål: Mit spørgsmål drejede sig om multipolaritet i selve Rusland og om det internationale samfunds holdning til Rusland, hvis det ikke overholder disse principper med hensyn til mord på journalister, frygt og angst, mangel på frihed, ngo'er.

Vladimir Putin: Det vil jeg sige et par ord om. Der var et andet spørgsmål, og det besvarede jeg, da jeg talte om sammensætningen af det russiske parlament. Se, hvem der er repræsenteret dér, og se på de politiske synspunkter hos dem, der indtager ledende stillinger i parlamentet, de legitime partier.

Hvad angår ngo'erne, så arbejder de aktivt i Rusland. Ja, vi har indført et nyt system til registrering af dem. Det adskiller sig ikke meget fra registreringssystemer i andre lande. $\mathrm{Og}$ foreløbig har vi ikke set nogen indvendinger fra ngo'erne selv. Vi har praktisk talt ikke nægtet nogen registrering. Der er to-tre tilfælde, hvor det er sket af formelle årsager, og disse ngo'er arbejder på at rette nogle bestemmelser i deres vedtægter osv. Der er ingen, der er blevet afvist af substantielle, fundamentale grunde. Alle arbejder meget aktivt, og det vil de fortsætte med.

Hvad bekymrer os? Jeg kan sige, og jeg tror, alle kan forstå det: Når disse ngo'er reelt finansieres af udenlandske regeringer, så betragter vi dem som instrumenter, fremmede stater kan bruge til at gennemføre deres politik over for vores 
land. Det var det første. For det andet: I alle lande er der bestemte regler for finansiering af $\mathrm{fx}$ valgkampe. Finansiering fra regeringskilder i andre lande går gennem ngo'erne, bl.a. inden for rammerne af regeringskampagner. Hvad skal det gøre godt for? Er det normalt demokrati? Det er skjult finansiering. Skjult for samfundet. Hvad er der demokratisk ved det? Kan De sige mig det? Nej, det kan De ikke og vil aldrig kunne! For det er ikke demokrati, men blot én stats indflydelse på en anden.

Men vi er interesserede i, at civilsamfundet udvikles i Rusland, at det skælder myndighederne ud og kritiserer dem, hjælper dem til at finde deres egne fejl og rette deres politik i borgernes interesse. Det er vi absolut interesserede $i$, og vi vil støtte civilsamfundet og ngo'erne.

Hvad angår frygt osv. Der er i dag mindre frygt hos os end i mange andre lande. I de seneste år har vi nemlig fuldstændig ændret situationen med hensyn til økonomien og borgernes velstand. Vi har stadig mange problemer. Vi har stadig mange uløste problemer, herunder problemer i forbindelse med fattigdom. Og jeg kan fortælle Dem, at frygten hovedsagelig stammer herfra.

Hvad angår journalisterne, så er det ganske rigtigt et stort og kompliceret problem. Journalister dræbes i øvrigt ikke kun i Rusland, men også i andre lande. Hvor er der dræbt flest journalister? De er jo specialist og kan sikkert sige, i hvilket land der er dræbt flest journalister i det sidste år til halvandet? Der er dræbt flest journalister i Irak.

Hvad angår tragedierne i vores land, så vil vi bestemt bekæmpe disse fænomener meget omhyggeligt og give hårde straffe til de forbrydere, der prøver at undergrave tilliden til Rusland og rokke ved vores politiske system.

Tak for Deres opmærksomhed.

Oversat fra russisk af Lars P. PoulsenHansen. 